1 Siliceous micro- and nanoplankton fluxes over the Northwind Ridge and their relationship to environmental conditions in the western

3

4

\title{
Arctic Ocean
}

Jian Ren ${ }^{\mathrm{a}, \mathrm{b}, \mathrm{c}}$, Jianfang Chen ${ }^{\mathrm{a}, \mathrm{b}, \mathbf{d}^{*}}$, Hongliang Li ${ }^{\mathrm{a}, \mathrm{b}}$, Martin G. Wiesner,d, Youcheng Bai ${ }^{\mathrm{a}, \mathrm{b}}$, Marie-Alexandrine Sicre ${ }^{\mathrm{e}}$, Zhixiong Yao ${ }^{\mathrm{b}, \mathrm{d}}$, Haiyan Jin ${ }^{\mathrm{a}, \mathrm{b}, \mathrm{d}}$, Yanpei Zhuang,b, Yangjie Li ${ }^{\mathrm{a}, \mathrm{b}}$

${ }^{a}$ Key Laboratory of Marine Ecosystem Dynamics, Ministry of Natural Resources, Hangzhou 310012, China

b Second Institute of Oceanography, Ministry of Natural Resources, Hangzhou 310012, China

c Southern Marine Science and Engineering Guangdong Laboratory (Zhuhai), Zhuhai 519000, China

d State Key Laboratory of Satellite Ocean Environment Dynamics, Second Institute of Oceanography, Ministry of Natural Resources, Hangzhou 310012, China

e Sorbonne Université, Campus Pierre et Marie Curie, LOCEAN, 4 place Jussieu, F-75005 Paris, France

* Corresponding author at: Key Laboratory of Marine Ecosystem Dynamics, Second Institute of Oceanography, Ministry of Natural Resources, Hangzhou 310012, China.

${ }^{*}$ E-mail: jfchen@ 0 sio.org.cn (Jianfang Chen) 


\section{Abstract}

Siliceous planktons are valuable indicators of the environmental conditions in both modern and past marine settings. However, in contrast to diatoms and radiolarians, other siliceous micro- and nanoplankton in the Arctic Ocean have been rarely explored. In this study, silicoflagellates, endoskeletal dinoflagellate Actiniscus pentasterias and chrysophyte cysts were investigated in one-year mooring sediment trap material (from August 2008 to September 2009) collected in the Northwind Ridge, western Arctic Ocean. The silicoflagellate assemblage was dominated by Stephanocha speculum, accounting for $>71 \%$ of the total silicoflagellate composition. While S. speculum was overwhelmingly abundant in summer, S. medianoctisol and S. octonarius were more frequent during winter. The export fluxes of endoskeletal dinoflagellate A. pentasterias did not show clear seasonal pattern except for a peak value in September 2009. We suggest that A. pentasterias reflects nutrient rich environment at sea ice edge rather than cold under sea ice conditions. High fluxes of chrysophyte cysts were recorded in summer 2009 peaking in late July and early August, 10 times higher than in summer 2008. Peak of chrysophyte cysts and sea ice melting occurred simultaneously. In addition, observed encystment might be triggered by the population density, hence indicating a favorable environment for phytoplankton blooming. These siliceous micro- and nanoplankton provides information on the modern Arctic Ocean environment but requires further investigations to consolidate knowledge for robust use in paleoceanography.

Keywords: Silicoflagellates, Endoskeletal dinoflagellate, Chrysophyte cysts, Siliceous micro- and nanoplankton, Arctic Ocean, Sediment trap 


\section{Introduction}

The Arctic sea ice extent has declined dramatically at a rate of $-12 \%$ per decade since 1979 (Comiso, 2012). Loss of the sea ice cover reduces the Arctic albedo and enhances heat exchange between the ocean and atmosphere, resulting in Arctic amplification on global climate change (Serreze et al., 2009). These changes have triggered fundamental transition in the Arctic marine ecosystem (e.g. Wassmann et al., 2011; Coupel et al, 2012; Lee et al., 2019; Nadaï et al., 2021). Decreasing size of phytoplanktons has been reported (Li et al., 2009; Morán et al., 2010), while annual net primary production (NPP) soared 30\% in recent decades owing to prolonged icefree period (Arrigo and Dijken, 2015). However, due to the lack of knowledge on the Arctic fauna and flora, our capacity to predict the future of the Arctic marine ecosystem is still limited.

Among siliceous planktons, Arctic diatoms and radiolarians are widely studied to understand their ecological niches and environmental preference (e.g. Katsuki et al., 2009; Ikenoue et al., 2015; Onodera et al., 2015; Lalande et al., 2019; Nadaï et al., 2021). The variability of diatom composition and fluxes derived from a sediment trap in the western Arctic during summer 2008 and 2009 have been related to surface currents change and sea ice distribution, showing their sensitivity to environmental alteration (Ren et al., 2020). However, other siliceous micro- and nanoplankton such as silicoflagellate, endoskeletal dinoflagellate Actiniscus pentasterias and chrysophyte cysts in the Arctic Ocean are sporadically reported (Zernova et al., 2000; Takahashi et al., 2009; Onodera et al., 2016), which has limited their use in monitoring Arctic environment changes. Knowledge on the ecology of siliceous micro- and nanoplankton is essential for interpreting paleoceanographic reconstructions.

The pioneering work on the geographic distribution of silicoflagellates in the surface sediments in the North Pacific has shown the close relationship between the silicoflagellate assemblages and sea surface temperature (Poelchau, 1976). Long sediment trap time series in the Bering and Chukchi Seas revealed that high relative abundances of Stephanocha medianoctisol are preferentially associated to colder conditions than S. speculum (Onodera and Takahashi 2005, 2012; Onodera et al., 2016), which is further supported by snapshot studies on the sea water and sea ice samples from the central and western Arctic Ocean (Takahashi et al., 2009; Onodera et al., 2016). 
By contrast, the temporal and spatial distribution of modern endoskeletal dinoflagellate $A$. pentasterias and chrysophyte cysts are seldom reported in high latitudes. Only a few time series and in situ sea water studies of A. pentasterias were carried out in the northern North Pacific (Takahashi, 1987; Onodera and Takahashi, 2007) and the Arctic (Onodera et al., 2016). Chrysophyte cysts are mostly found in fresh waters while they are much less common in marine samples (Smol, 1988; Duff et al., 1995; Zeeb and Smol, 2001). Fossil chrysophyte cysts found in marine sediments and not related to modern species were assigned to the artificial family Archaeomonadaceae (Deflandre and Deflandre-Rigaud, 1969). They have been encountered in sediments as old as the Early Cretaceous (e.g. Harwood and Gersonde, 1990). A few studies on chrysophyte cysts in the surface sediments in polar region have linked their distribution to sea ice (Mitchell and Silver, 1982, 1986; Redmond Roche, 2019). Overall, these results show that our understanding of chrysophyte cysts in the modern Arctic Ocean is still very limited.

Here, we present a one-year sinking flux record of siliceous micro- and nanoplanktons (silicoflagellates, endoskeletal dinoflagellate Actiniscus pentasterias and chrysophyte cysts) obtained from a sediment trap deployed over the Northwind Ridge, western Arctic Ocean, from August 2008 to September 2009. Fluxes of siliceous micro- and nanoplankton combined with that of diatoms and biomarkers from the same sediment trap (Bai et al., 2019; Ren et al., 2020) were used to 1) document the temporal variation of siliceous micro- and nanoplanktons and 2) unravel the relationship between these siliceous planktons and surface ocean environmental conditions in the western Arctic Ocean. 


\section{Regional setting}

The study area is located at the southern Northwind Ridge, western Arctic Ocean and characterized by seasonal sea ice. The sea ice cover starts to decrease in summer and retreats to a minimum over the northern Chukchi Sea in September, prior to an entire coverage of the study area from November to July (Fig. 1a; Fig. 2a-b). During the melting season, the study area sits in the marginal ice zone (MIZ), an interaction belt between sea ice and open ocean, where primary production is boosted (Kędra et al., 2015; Wassmann, 2015).

The region is also influenced by the surface water mass from different sources: the fresh and oligotrophic waters of the Beaufort Gyre (BG) driven by the Beaufort High (Proshutinsky and Johnson, 1997), the Pacific Water Inflow (PWI) transporting the saline and eutrophic Anadyr Water (AW), the fresher and nutrient-depleted Alaska Coastal Water (ACW) and the Bering Shelf Water (BSW) in the Chukchi Sea (Fig. 1a; Woodgate et al., 2005; Grebmeier et al., 2006). In addition, the Siberian Coastal Current (SCC) occasionally converges with the PWI and trespasses to the Chukchi Borderland (Weingartner et al., 1999).

In summer, the upper $10 \mathrm{~m}$ water column is composed of the relatively warm, fresher, nutrient depleted surface mixed layer overlying the colder, saline and nutrient-rich PWI consisting of Pacific Summer Water (PSW) in 50-100 m water depths and Pacific Winter Water (PWW) in 100-150 m that sometimes extends to deeper than $200 \mathrm{~m}$ (Woodgate, 2013). The PWI is thus a major source of nutrients for the western Arctic Ocean (Walsh et al., 1997; Grebmeier et al., 2006).

In summer 2008, the western Arctic was characterized by a strong BG inferred from the higher Arctic Ocean Oscillation (Proshutinsky et al., 2015), oligotrophic conditions associated with relatively low transport of eutrophic PWI (Woodgate et al., 2015; Woodgate, 2018), resulting in a reduced biogenic production (Ren et al., 2020). In summer 2009, by contrast, intensified PWI and weakened BG accounted for higher phytoplankton fluxes (Ren et al., 2020). Sea ice distribution pattern also influenced primary production in 2008 and 2009, respectively (Fig. 1b-c; Fig. 2c-d; Ren et al., 2020). 


\section{Material and Methods}

\subsection{Sediment trap samples}

A mooring system was deployed for one year at Station DM, Northwind Ridge, from August 2008 to September 2009 (Fig. 1a; $74^{\circ} 24.0^{\prime}$ N, $158^{\circ} 14.0^{\prime}$ W, $1650 \mathrm{~m}$ water depth). The sediment trap (McLane Mark78H-21) equipped with 21 sampling cups was installed at $\sim 870 \mathrm{~m}$ water depth. The cups were filled with artificial seawater (salinity $\approx 35$ ) and $\mathrm{HgCl}_{2}$ as antiseptic before deployment. From July to November, the sampling interval was set around half month (15 or 16 days) and to one month (28 to 31 days) between December and June (Table S1; Bai et al., 2019). After recovery of the sediment trap, all samples were sieved by a 1-mm mesh nylon sieve to remove swimmers. Particles $<1 \mathrm{~mm}$ were then divided into equal aliquots with a McLane wet sample divider (WSD-10) and one aliquot was filtered onto a polycarbonate filter ( $47 \mathrm{~mm}$ diameter with $0.45 \mu \mathrm{m}$ pore size). The filters were then dried in an oven at $45^{\circ} \mathrm{C}$ for 72 h (Bai et al., 2019).

\subsection{Slides preparation and identification of siliceous planktons}

Quantitative slides for siliceous micro- and nanoplankton were processed using the residue of the diatom slides prepared by Ren et al. (2020), following the standard method of Gersonde and Zielinski (2000). Residues were generated by treatment with $\mathrm{HCl}(\sim 36 \%)$ and $\mathrm{H}_{2} \mathrm{O}_{2}(\sim 30 \%)$ of the subsamples of each cup ( 30 or $15 \mathrm{mg}$, dependent on sample amount). An aliquot of a known amount of the rinsed residue was then dropped on a cover glass $(24 \times 24 \mathrm{~mm})$ by settling in a Petri dish. The permanent slides for siliceous micro- and nanoplankton were mounted with Naphrax $\left(n_{D} \sim 1.7\right)$. Only $1 \mathrm{mg}$ of subsample was available for cup 14 (May 2009), but was analyzed in order to keep an intact record.

Around 100 skeletons of silicoflagellates (max. 137, min. 90) were counted for each slide with a Motic BA410E microscope at $\times 400$ magnification. Fewer skeletons were found in cup 14 (31 skeletons) and 16 (67 skeletons) due to low specimen content in the samples. Specimens of endoskeletal dinoflagellate Actiniscus pentasterias and chrysophyte cysts were counted meanwhile. Specimen numbers per slide ranged from 8 to 205 for Actiniscus pentasterias (mostly $>20$ specimens) and from 22 to 1487 for chrysophyte cysts, respectively. Ebridians were found in a few slides but not reported here because of their low content (1-3 specimen per 
sample). Only the specimens with intact main bodies were counted.

Silicoflagellates were identified to species level based primarily on the studies in the Arctic Ocean of Takahashi et al. (2009) and Onodera et al. (2016) as well as those in the subarctic Pacific of Takahashi (1987) and Onodera and Takahashi (2007, 2012). The illegitimate genus Distephanus has been replaced by Stephanocha according to Jordan and McCartney (2015). Actiniscus pentasterias was identified according to Orr and Conley (1976) and Onodera et al. (2016). Given the difficulties to identify chrysophyte cysts at a taxonomy level and the uncertainties to relate these cysts to their vegetative form, we only used chrysophyte cysts as the group of specimens represented by siliceous spheres, generally of $\sim 5-10 \mu \mathrm{m}$ in diameter, with a single pore (Adam and Mahood, 1981; Mitchell and Silver, 1982). Because debates are still going on whether chrysophyte cysts and Archaeomonadaceae (marine fossil chrysophyte cysts that do not relate to modern vegetative forms) belong to the same taxonomy (Adam and Mahood, 1981; Mitchell and Silver, 1982), we only use chrysophyte cysts to avoid taxonomic difficulties. The taxonomy of chrysophyte cysts used herein refers to Duff et al. (1995) and Wilkinson et al. (2001). Most chrysophyte cysts, due to their diverse morphology and variable mature and immature ornamentation, have not been related to the vegetative cells that produce them (Zeeb and Smol, 2001). Therefore, we cannot robustly identify the original taxa of chrysophyte cysts of this study. Moreover, identification of chrysophyte cysts to subgroups was also limited owing to the small size of the cysts under light microscopy.

\subsection{Scanning electron microscope images}

Diluted aliquots of the residues of the diatom slides were pipetted onto polycarbonate filters $(0.45 \mu \mathrm{m}$ pore size, $47 \mathrm{~mm}$ in diameter). Part of the dried filters were mounted on the stubs of the scanning electron microscope (SEM) with double-sided adhesive tapes. The stubs were coated with platinum (Pt) for 2 minutes by a Hitachi MC1000 Ion Sputter Coater. A Hitachi SU8010 Field-Emission Scanning Electron Microscope (FE-SEM) at $3.0 \mathrm{kV}$ was then used to take photomicrographs of siliceous micro- and nanoplankton.

\subsection{Relative abundances and fluxes}

The silicoflagellate counts were converted into relative abundances with respect to the total silicoflagellate assemblage. 
The fluxes of siliceous micro- and nanoplankton were calculated using the equation given in Ren et al. (2020). First, the plankton concentrations (skeletons/cysts per milligram dry sample) were estimated with the following equation:

$$
\text { Concentration }=(1 / d w) \times(c s a / t a) \times(s v / s p l i t) \times(v n / t n)
$$

where $d w$ is the dried sample weight in milligrams, csa is the area of the cover slide (576 $\left.\mathrm{mm}^{2}\right), t a$ is the area of one counted traverse $\left(15 \mathrm{~mm}^{2}\right), \quad s v$ is the volume of processed suspension $(6-15 \mathrm{ml})$, split is the volume of aliquot onto the cover slide (from 0.81 to 1.36 $\mathrm{ml}), v n$ is the total counted micro- and nanoplankton skeleton/cyst number and the $t n$ is the number of fully counted traverses.

Then fluxes (skeletons/cysts per square meters per day) were calculated using:

in which the total mass flux (milligram dry sample per square meters per day) are those of Bai et al. (2019) and concentration those obtained from the previous equation.

\subsection{Biomarker and Environmental data}

The fluxes of the biomarkers (IP $25, \mathrm{HBI}-\mathrm{III}$, brassicasterol, dinosterol) derived from the same sediment trap collected at Station DM were obtained from Bai et al. (2019).

Daily sea ice concentration and thickness data at Station DM for the studied period were retrieved from the National Centers for Environmental Prediction (NCEP)/Climate Forecast System Reanalysis (CFSR) 6-hourly dataset (Saha et al., 2010, 2014). In this study we consider July, August and September as summer months and November to April as winter months according to the sea ice concentration and thickness.

The Arctic Ocean Oscillation index used to indicate the strength of the Beaufort Gyre were the values of Proshutinsky et al. (2015).

Monthly transport volume of PWI were obtained from the "Bering Strait: Pacific Gateway to the Arctic" project (Woodgate et al., 2015; Woodgate, 2018). 


\section{Results}

\subsection{Silicoflagellates}

Silicoflagellate fluxes were high $\left(>20 \times 10^{3}\right.$ skeletons $\left.\mathrm{m}^{-2} \mathrm{~d}^{-1}\right)$ for both summers, while much lower values were found in winter when Station DM was covered by sea ice (mostly $<10$ $\times 10^{3}$ skeletons $\mathrm{m}^{-2} \mathrm{~d}^{-1} ;$ Fig. 2a, b, f). The extreme peak flux of $\sim 540 \times 10^{3}$ skeletons $\mathrm{m}^{-2} \mathrm{~d}^{-1}$ was encountered in late September 2009, synchronous with the maximum total mass flux (Fig. 2e, f). Late July 2009 saw an abrupt rise of silicoflagellate flux from $\sim 2 \times 10^{3}$ to $\sim 80 \times 10^{3}$ skeletons $\mathrm{m}^{-2} \mathrm{~d}^{-1}$, coinciding with the onset of sea ice decreasing (Fig. 2a, f).

The silicoflagellate assemblage was dominated by Stephanocha speculum, which on average accounted for more than $71 \%$ of total silicoflagellate composition (Fig. 3, 4a). The relative abundance of $S$. speculum showed clear seasonal variations. It reached over $80 \%$ during both summers and decrease to a minimum of $63 \%$ in winter (Fig. 3b). The second most abundant species, S. medianoctisol, contributed $\sim 20 \%$ of annual total silicoflagellate (Fig. 3b, 4 b). In contrast, S. medianoctisol was more abundant in winter ( $24 \%)$ than in summer $(\sim 12 \%$; Fig. 3b). Likewise, S. octonarius accounted for $\sim 4 \%$ of the total assemblage in winter (Fig. 3b, 4c). Pentagonal S. quinquangellus was a minor component $(<1 \%$ on average). Only a few double skeletons were observed, most of which were S. speculum and occurred in summer. They were generally $<2 \%$ of the silicoflagellate assemblage.

\subsection{Endoskeletal dinoflagellate Actiniscus pentasterias}

Actiniscus pentasterias (Fig. 4d-f) fluxes were extremely high in summer 2009, especially in late September $\left(71 \times 10^{3}\right.$ skeletons $\left.\mathrm{m}^{-2} \mathrm{~d}^{-1} ; \mathrm{Fig} .2 \mathrm{~g}\right)$. The fluxes during other periods were mostly below $6 \times 10^{3}$ skeletons $\mathrm{m}^{-2} \mathrm{~d}^{-1}$. While higher values were found in October and November $2008\left(\sim 7 \times 10^{3}\right.$ skeletons $\left.\mathrm{m}^{-2} \mathrm{~d}^{-1}\right)$, minimum fluxes, lower than $2 \times 10^{3}$ skeletons $\mathrm{m}^{-2}$ $\mathrm{d}^{-1}$, were recorded in June and early July 2009. There was no clear seasonal pattern observed (Fig. 2g).

\subsection{Chrysophyte cysts}


240 exhibited high values, with chrysophyte cysts fluxes in summer 2009 at least twice as much as

241 those of summer 2008 (Fig. 2h). Striking high fluxes peaked at $\sim 932 \times 10^{3}$ and $\sim 817 \times 10^{3}$ cysts

$242 \mathrm{~m}^{-2} \mathrm{~d}^{-1}$ in late July and early August 2009, respectively, nearly 10 times higher than those of

243 summer 2008. By contrast, winter fluxes were generally lower than $20 \times 10^{3}$ cysts $^{-2} \mathrm{~d}^{-1}$. 


\section{Discussion}

\subsection{Silicoflagellates and their oceanographic features}

Our data at the Northwind Ridge revealed higher silicoflagellate fluxes in summer 2009 than in 2008 and a seasonal pattern of the silicoflagellate assemblage (Fig. 3a). The relative abundance of the dominant species $S$. speculum was higher in summer, while that of $S$. medianoctisol and S. octonarius increased under sea ice cover (Fig. 3b). Similar seasonal pattern of silicoflagellate assemblage was also evidenced in the nearby sediment trap in the Northwind Abyssal Plain, western Arctic (NAP in Fig. 1a; Onodera et al., 2016), with $S$. medianoctisol and S. octonarius accounting for $>30 \%$ of total silicoflagellate assemblage in summer 2010 (Onodera et al., 2016). These two species were reported as predominant in the central and the western Arctic, where sea ice prevailed (Melnikov, 1997; Melnikov et al., 2002; Takahashi et al., 2009). Highest relative abundance of S. medianoctisol in sediment traps from the subarctic Pacific were found to be correlated to colder conditions (Onodera and Takahashi, 2012). It is thus likely that $S$. medianoctisol and $S$. octonarius tolerate sea ice and cold water and therefore that their high abundances in silicoflagellate assemblages are indicative of freezing conditions. This could explain that relative abundances of $S$. medianoctisol and $S$. octonarius were higher in summer 2009 when ice free conditions lasted approximately one month less than in 2008 (Fig. 2a, f, 3b). The biometry of S. medianoctisol, notably the spine length has been proposed as an indicator to discriminate sea ice and seawater habitats in the central Arctic (Tsutsui and Takahashi, 2009). However, this morphological parameter was not measured in this study. Further studies on the relationship between the biometry of silicoflagellate and their dwelling environment should be explored to refine this tool.

The six-sided S. speculum represented less than $70 \%$ in winter except for one single sample in May 2009, most likely biased by insufficient sample amount (Fig. 3b). These results are in line with the silicoflagellate composition from the nearby NAP site (Onodera et al., 2016) and other studies, showing that $S$. speculum is a common species at high latitudes that dominates the silicoflagellate assemblage of sinking particles and sediments north of the Subarctic Front in the North Pacific (Poelchau, 1976; Takahashi, 1985, 1987; Onodera and Takahashi, 2005, 2012). Based on its distribution in the North Pacific, Onodera et al. (2016) inferred that $S$. 
speculum might be indicative of mesotrophic to eutrophic conditions. Higher S. speculum fluxes in summer 2009 than in 2008 (Fig. 3a) are in agreement with the high diatom fluxes (Ren et al., 2020) and enhanced PWI in 2009 entraining more nutrient to our site (Woodgate et al., 2012; Woodgate, 2018). If higher S. speculum is indeed related to increased productivity due to nutrient supply, this species could also be regarded as a productivity indicator as proposed by Takahashi (1989). Furthermore, S. speculum was found abundant in the Bering Sea ( $>60 \%$ in sediment; Poelchau, 1976; $>80 \%$ in sediment trap; Onodera and Takahashi, 2012) and less frequent in the central Arctic ( $<29 \%$; Takahashi et al., 2009), suggesting that it might reflect subarctic conditions in the area.

Most of double skeletons in our sediment trap material, though in low abundance, were encountered in summer, which could imply silicoflagellate reproduction and higher production during phytoplankton blooming when sea ice retreats (Takahashi et al., 2009; Onodera et al., 2016). However, the relative abundance of summer silicoflagellate double skeletons at Station $\operatorname{DM}(<2 \%)$ were much less than that of the nearby NAP site ( $>10 \%$; Onodera et al., 2016). This difference could suggest interannual variability or regional difference although methodological bias cannot be ruled out. Slide preparation, which might damage organic coat of double skeletons and separate them into single skeletons, accounts at least in part for this discrepancy.

Only a few studies have used silicoflagellate assemblages to reconstruct paleoenvironmental conditions in the Pacific-Arctic region (Onodera et al., 2016; Teraishi et al., 2016). Past oceanographic variability of the Gulf of Alaska for the past 15000 years has been established partly based on fossil silicoflagellate assemblages (Barron et al., 2009). Higher abundances of S. medianoctisol were also reported in the Bering Shelf break sediments during glacial periods of the early- to mid-Pleistocene corresponding to the cold intervals (Teraishi et al., 2016). A close relationship between the sea surface temperatures (SSTs) and the ratio of $S$. medianoctisol to S. speculum was highlighted by Onodera and Takahashi (2012) and used in sediment cores to estimate semi-quantitatively temperature variability (e.g. Ciesielski and Weaver, 1974). Yet, longer observation time series would be required to consolidate this relationship.

\subsection{Endoskeletal dinoflagellate and productivity}


Higher fluxes of endoskeletal dinoflagellate Actiniscus pentasterias were found in winter

in the Northwind Abyssal Plain, under sea ice conditions (NAP in Fig. 1a; Onodera et al., 2016). However, except for peaking value in summer 2009, the fluxes of A. pentasterias at Station DM did not show a clear seasonal variability (Fig. 2g). This species has also been found in the subarctic (Takahashi, 1987) and tropical Pacific (Takahashi, 1991) indicating a possible wider distribution range. Steidinger and Tangen (1997) further showed the cosmopolitan occurrence of $A$. pentasterias from subtropical to cold temperate oceans. Low fluxes of $A$. pentasterias at our site in winter suggest that this species does not dwell under the ice. Interestingly, in summer 2010 living A. pentasterias occurred in high abundances close to the sea ice edge (Onodera et al., 2016) in accordance with high flux values in summer 2009 at Station DM during the ice melting season (Fig. 2g). Therefore, given its wide distribution, A. pentasterias is unlikely to be an indicator of cold conditions. On the contrary, as a heterotroph, A. pentasterias is likely to be more sensitive to phytoplankton seasonal blooming, as its food supply, than to cold or warm environmental conditions. Besides, the fluxes of A. pentasterias are highly correlated with those of silicoflagellate $\left(r^{2}=0.97, p<0.01\right)$, as well as to cold water diatoms $\left(r^{2}=0.65, p<0.01\right)$ and open water phytoplankton biomarker brassicasterol $\left(r^{2}=0.88, p<0.01\right)$, featuring the close relationship between A. pentasterias and its prey (Table 1). Therefore A. pentasterias thriving under fertile conditions favoring phytoplankton blooms would portray productive MIZ environment as also suggested by sediment traps data from northern North Pacific (Takahashi, 1987).

\subsection{Chrysophyte cysts as environmental indicators}

Although most chrysophytes inhabit fresh water systems (Duff et al., 1995; Zeeb and Smol, 2001 and references therein), they have also been described in marine settings (Peters and Andersen, 1993; Berard-Therriault et al., 1999). A few species of chrysophytes have been observed in the Arctic Ocean (Coupel et al., 2012; Lee et al., 2012; Ardyna et al., 2017; Assmy et al., 2017), whereas chrysophyte cysts are rarely detected. Yet fossil chrysophyte cysts have been found in Arctic sediments as old as Eocene (Stickley et al., 2008). According to the morphology and ornamentation of chrysophyte cysts, it is likely that the cysts at Station DM (Fig. 4g-i) are stomatocysts No. 381 and 382 as described by Wilkinson et al. (2001) in 
sediments of a Canadian Arctic lake that corresponds to a marine period (Wilkinson et al., 2001). If so, chrysophyte cysts found in our sediment trap would be indicative of an Arctic marine origin rather than fresh water. The fluxes of chrysophyte cysts in summer 2009 were one order of magnitude higher than those of summer 2008 (Fig. 2h) with maximum fluxes in late July to early August 2009 that were $\sim 4$ to 5 times greater than the rest of that summer (Fig. $2 \mathrm{~h}$ ). In addition, according to in situ measurements the surface layer near Station DM was fresher in summer 2008 than in summer 2009 (Zhang, 2009; Kikuchi, 2009) and the freshwater volume of the upper $30 \mathrm{~m}$ layer did not vary much during the blooming season as calculated from NCEP/CFSR dataset (Saha et al., 2010, 2014). Consequently, the freshwater origin of chrysophyte cysts at our site can be excluded.

It is also unlikely that chrysophyte cysts were transported by currents from brackish coastal areas. Higher fluxes of allochthonous diatoms (e.g. Chaetoceros resting spores and Paralia sulcata) and terrestrial biomarkers (campesterol and $\beta$-sitosterol) were recorded in summer 2009 and attributed to enhanced PWI bringing coastal material from the shallow Chukchi shelf region to the Northwind Ridge (Ren et al., 2020). Allochthonous material showed high fluxes over the entire summer 2009. In contrast, chrysophyte cysts were massively abundant from late July and early August of $2009\left(>800 \times 10^{3}\right.$ cysts $\left.\mathrm{m}^{-2} \mathrm{~d}^{-1}\right)$ and dropped by 4 fold the following summer (Fig. 2h), which does not match with the high transport of PWI in 2009 (Fig. 2d; Woodgate et al., 2015; Woodgate, 2018). Sea ice may have played a role in the transport of the cysts to the study site but the high fluxes in ice free waters in late August and September make this hypothesis improbable (Fig. 2a, h). It is thus very likely that chrysophyte cysts underwent in situ encystment after blooming at our site. Besides, the echinate spines on the surface of chrysophyte cysts were mostly intact and unbroken (Fig. 4g-i) in agreement with gentle rather than stirring surface current transport.

As earlier mentioned, peaking fluxes coincide with enhanced sea ice melting in summer (Fig. 2a, b, h). It is thus possible that chrysophyte cysts are associated to sea ice, akin to some sea ice diatoms as suggested by Mitchell and Silver (1982, 1986). Most reports linking chrysophyte cysts to sea ice are from the Southern Ocean (e.g. Silver et al., 1980; Takahashi et al., 1986; Riaux-Gobin and Stumm, 2006; Riaux-Gobin et al., 2011), and may therefore relate 
to different species from our study. Nevertheless, the response of chrysophyte cysts to sea ice decline does not parallel that of sea ice diatoms (Ren et al., 2020). Although both increased abruptly late July 2009, the diatoms fluxes fluctuated much less than the cysts (Fig. 5; Ren et al. 2020). The correlation between the fluxes of chrysophyte cysts and sea ice diatoms is hence not significant $\left(r^{2}=0.31, p<0.01\right.$; Table 1$)$. Comparison between the fluxes of chrysophyte cysts and sea ice biomarker $\mathrm{IP}_{25}$ from the same sediment trap material does not show similar seasonal variability (Table 1; Bai et al., 2019). Neither does the cysts and sea ice margin biomarker HBI-III (Table 1). It is thus hard to conclude on the exact link between the chrysophyte cysts and sea ice. Surface sediments from the northern North Atlantic have shown that chrysophyte cysts mainly occured between the winter maximum and summer minimum sea ice boundaries, where MIZ lies (Redmond Roche, 2019). According to light microscopic determination, this species is similar to that found at our site (Redmond Roche, 2019) suggesting that chrysophyte cysts are related at least to chilly environment.

Chrysophyte cysts are formed either asexually or sexually (Sandgren, 1991; Duff et al., 1995 and references therein). Although sexually induced cysts are still poorly studied, previous studies demonstrated that the sexual formation of cysts, as least for the investigated species, are possibly triggered by population density rather than environmental stress (Sandgren, 1991; Duff et al., 1995). Therefore, the maximum fluxes of chrysophyte cysts in late July and early August might be a consequence of specific environmental conditions that promoted the growth of chrysophyte vegetative cells and initiated the encystment when the cells number exceeded the population threshold. It is likely that peaking chrysophyte cysts in summer 2009 witnessed favorable conditions for phytoplankton blooming stimulated by enhanced light penetration caused by sea ice thinning and melting at the MIZ (Fig. 2a, b) together with increased nutrient supply from strengthened PWI (Fig. 2d; Ren et al., 2020). Therefore, high abundances of chrysophyte cysts might indicate a propitious environment for phytoplankton thriving (e.g. high nutrients) under cold condition.

\subsection{Relationship between siliceous plankton and environmental conditions}

The fluxes of silicoflagellate, endoskeletal dinoflagellate $A$. pentasterias and chrysophyte cysts show no significant correlation with sea ice proxies, i.e. sea ice diatom and $\mathrm{IP}_{25}$ (Table 1). 
389 They instead seem to be more tightly associated to cold water diatoms and phytoplankton

390 biomarkers (brassicasterol and dinosterol; Table 1). This implies that these siliceous planktons

391 are more akin to MIZ rather than permanent ice zone. However, due to the temporal and spatial

392 limitation of this times series, it is hard to unravel whether these siliceous planktons are sea ice

393 inhabitants. Significant correlations between the fluxes of silicoflagellate and A. pentasterias

$394\left(r^{2}=0.97, p<0.01\right)$ as well as between chrysophyte cysts and dinosterol, a biomarker produced

395 by dinoflagellates $\left(r^{2}=0.56, p<0.01\right.$; Table 1$)$ suggest the food web relationship between preys

396 and predators.

397

398 


\section{Summary and Conclusions}

400

401

402

403

404

405

406

407

408

409

410

411

412

The one-year flux record of siliceous micro- and nanoplankton acquired at the Northwind Ridge, western Arctic Ocean, between August 2008 and September 2009 highlights the strong seasonality of the production and export of silicoflagellates, endoskeletal dinoflagellates Actiniscus pentasterias and chrysophyte cysts. The dominant silicoflagellate Stephanocha speculum prevailed in summer, while S. medianoctisol and S. octonarius were more frequent in winter. These findings suggest that $S$. speculum might reflect subarctic conditions and influence of Pacific waters through the Bering Strait while S. medianoctisol and S. octonarius would closely link to sea ice and associated cold conditions. Abundances of A. pentasterias were found to be manifesting productive conditions at the MIZ. Similarly, chrysophyte cysts were overwhelming abundant during ice melting suggesting favorable conditions for phytoplankton blooming. Overall, these groups of siliceous micro- and nanoplankton provide environmental information, complementary to diatoms, depicting modern and past changes in the Arctic Ocean. We suggest to explore further the potential of these siliceous micro- and nanoplankton for paleoceanographic studies in the western Arctic as they require fewer species identification compared to diatoms, while sharing similar processing methodology. A deeper understanding of their ecology will entail investigation of their long-term temporal variability and spatial distribution both in water column and surface sediments. 


\section{Acknowledgements}

We sincerely thank the scientific party and crew members of the $\mathrm{R} / \mathrm{V}$ Xuelong for deployment and recovery of the sediment trap at Station DM. We are grateful to Dr. Richard Jordan of Yamagata University, Dr. Jonaotaro Onodera of Japan Agency for Marine Earth Science and Technology (JAMSTEC), and Dr. Oliver Esper of Alfred-Wegener-Institut Helmholtz-Zentrum für Polar-und Meeresforschung (AWI) for their kind help on chrysophyte cyst taxonomy. Dr. Nianhang Rong and Dr. Xi Zheng of Analysis Center of Agrobiology and Environmental Sciences, Zhejiang University is acknowledged for their technical assistance on scanning electron microscope (SEM) photomicrography. Dr. Long Lin of State Key Laboratory of Satellite Ocean Environment Dynamics, Second Institute of Oceanography is thanked for his helpful advice on the freshwater estimation. We are also indebted to Dr. Xi Tang of East China Normal University for his help on the artwork. This study was funded by the National Natural Science Foundation of China (Nos. 42076241, 41606052, 41941013, 41976229), the Scientific Research Funds of the Second Institute of Oceanography, State Oceanic Administration, China (Nos. JG1611, JG1911), the Chinese Polar Environmental Comprehensive Investigation and Assessment Programs (No. CHINARE 0304) and the Cai Yuan Pei Program/ICAR (Sea Ice melt, Carbon, Acidification and Phytoplankton in the present and past Arctic Ocean) funded by China Scholarship Council. We are also grateful to Centre National de la Recherche Scientifique (CNRS) for MAS salary support. We thank three anonymous reviewers for constructive comments to improve the manuscript. 


\section{References}

Adam, D.P., Mahood, A.D., 1981. Chrysophyte cysts as potential environmental indicators. Geological Society of America Bulletin, Part 1, 92, 839-844.

Ardyna, M., Babin, M., Devred, E., Forest, A., Gosselin, M., Raimbault, P., Tremblay, J.-É., 2017. Shelf-basin gradients shape ecological phytoplankton niches and community composition in the coastal Arctic Ocean (Beaufort Sea). Limnology and Oceanography, 62, 2113-2132.

Arrigo, K.R., van Dijken, G.L., 2015. Continued increases in Arctic Ocean primary production. Progress in Oceanography, 136, 60-70.

Assmy, P., Fernández-Méndez, M., Duarte, P, Meyer, A., Randelhoff, A., Mundy, C.J., Olsen, L.M., Kauko, H.M., Bailey, A., Chierici, M., Cohen, L., Doulgeris, A.P., Ehn, J.K., Fransson, A., Gerland, S., Hop, H., Hudson, S.R., Hughes, N., Itkin, P., Johnsen, G., King, J.A., Koch, B.P., Koenig, Z., Kwasniewski, S., Laney, S.R., Nicolaus, M., Pavlov, A.K., Polashenski, C.M., Provost, C., Rösel, A., Sandbu, M., Spreen, G., Smedsrud, L.H., Sundfjord, A., Taskjelle, T., Tatarek, A., Wiktor, J., Wagner, P.M., Wold, A., Steen, H., Granskog, M.A., 2017. Leads in Arctic pack ice enable early phytoplankton blooms below snow-covered sea ice. Scientific Reports, 7, 40850. doi: 10.1038/srep40850.

Bai, Y., Sicre, M.-A., Chen, J., Klein, V., Jin, H., Ren, J., Li, H., Xue, B., Ji, Z., Zhuang, Y., Zhao, M., 2019. Seasonal and spatial variability of sea ice and phytoplankton biomarker flux in the Chukchi Sea (western Arctic Ocean). Progress in Oceanography, 171, 22-37.

Barron, J.A., Bukry, D., Dean, W.E., Addison, J.A., Finney, B., 2009. Paleoceanography of the Gulf of Alaska during the past 15,000 years: results from diatoms, silicoflagellates, and geochemistry. Marine Micropaleontology, 72, 176-195.

Bérard-Therriault, L., Poulin, M., Bossé. L., 1999. Guide d'identification du phytoplancton marin de l'estuaire et du golfe du Saint-Laurent incluant également certains protozoaires. Publ. spéc. Can. sci. halieut. aquat. 128, 387 p. doi: 10.1139/9780660960579

Bohaty, S.M., Harwood, D.M., 1998. Southern Ocean Pliocene paleotemperature variation high-resolution silicoflagellate biostratigraphy. Marine Micropaleontology, 33, 241-272.

Ciesielski, P.F., Weaver, F.M., 1974. Early Pliocene temperature changes in the Antarctic seas. Geology, 2, 511-515.

Comiso, J.C., 2012. Large decadal decline of the Arctic multiyear ice cover. Journal of Climate, $25,1176-1193$.

Coupel, P., Jin, H., Joo, M., Horner, R., Bouvet, H.A., Sicre, M.-A., Gascard, J.-C., Chen, J.F., 
Garçon, V., Ruiz-Pino, D., 2012. Phytoplankton distribution in unusually low sea ice cover over the Pacific Arctic. Biogeosciences 9, 4835-4850.

Crosta, X., Koç, N., 2007. Diatoms: from micropaleontology to isotope geochemistry. In: Hillaire-Marcel, C., de Vernal, A. (Eds), Proxies in Late Cenozoic Palaeoceanography, 327369pp.

Deflandre, G., Delfandre-Rigaud, M., 1969. Nannofossiles siliceux I: Archaeomonadaceae: Fichier Micro paleontologique General, Ser. 19, ix p. +119 plates.

Duff, K.E., Zeeb, B.A., Smol, J.P., 1995. Atlas of Chrysophycean Cysts. Kluwer Academic Press, Dordrecht, 189 pp.

Gersonde, R., Zielinski, U., 2000. The reconstruction of late Quaternary Antarctic sea ice distribution - the use of diatoms as a proxy for sea ice. Palaeogeography, Palaeoclimatology, Palaeoecology, 162, 263-286.

Grebmeier, J.M., Cooper, L.W., Feder, H.M., Sirenko, B.I., 2006. Ecosystem dynamics of the Pacific-influenced northern Bering and Chukchi seas in the Amerasian Arctic. Progress in Oceanography, 71, 331-361.

Harwood, D.M., Gersonde, R., 1990. Lower Cretaceous diatoms from ODP Leg 113 Site 693 (Weddell Sea), Part 2. Resting spores, chrysophycean cysts, an endoskeletal dinoflagellate, and notes on the origin of the diatoms. In: Barker, P.F., Kennett, J.P., et al. (Eds), Proc. ODP, Sci. Results, 113: College Station, TX (Ocean Drilling Program), 403-425 pp. doi:10.2973/odp.proc.sr.113.201.1990

Ikenoue, T., Bjørklund, K.R., Krugulikova, S.B., Onodera, J., Kimoto, K., Harada, N., 2015. Flux variations and vertical distributions of siliceous Rhizaria (Radiolaria and Phaeodaria) in the western Arctic Ocean: indices of environmental changes. Biogeosciences, 12, 2019-2046.

Jordan, R.W. and McCartney, K., 2015. Stephanocha nom. nov., a replacement name for the illegitimate silicoflagellate genus Distephanus (Dictyochophyceae). Phytotaxa, 201, 177-187.

Katsuki, K., Takahashi, K., Onodera, J., Jordan, R.W., Suto, I., 2009. Living diatoms in the vicinity of the North Pole, summer 2004. Micropaleontology, 55, 137-170.

Kędra, M., Moritz, C., Choy, E.S., David, C., Degen, R., Duerksen, S., Ellingsen, I., Górska, B., Grebmeier, J.M., Kirievskaya, D., van Oevelen, D., Piwosz, K., Samuelsen, A., Węsławski, J.M., 2015. Status and trends in the structure of Arctic benthic food webs. Polar Research, 34:1, 23775, DOI: 10.3402/polar.v34.23775

Kikuchi, T., 2009. R/V Mirai Cruise Report MR09-03. JAMSTEC, Yokosuka, 190p. 
Lalande, C., Nöthig, E.-M., Fortier, L., 2019. Algal export in the Arctic Ocean in times of global warming. Geophysical Research Letter, 46, 5959-5967, https://doi.org/10.1029/2019GL083167

Lee, S.H., Joo, H.M., Yun, M.S., Whitledge, T.E., 2012. Recent phytoplankton productivity of the northern Bering sea during early summer in 2007. Polar Biology, 35, 83-98.

Lee, Y., Min, J.-O., Yang, E.J., Cho, K.-H., Jung, J., Park, J., Moon, J.K., Kang, S.-H., 2019. Influence of sea ice concentration on phytoplankton community structure in the Chukchi and East Siberian Seas, Pacific Arctic Ocean. Deep-Sea Research Part I, https://doi.org/10.1016/j.dsr.2019.04.001.

Li, W.K., Mclaughlin, F.A., Lovejoy, C., Carmack, E.C., 2009. Smallest algae thrive as the Arctic Ocean freshens. Science 326, 539.

Melnikov, I.A., 1997. The Arctic Sea Ice Ecosystem. Gordon and Breach Science Publishers, Amsterdam, 204 pp.

Melnikov, I.A., Kolosova, E.G., Welch, H.E., Zhitina, L.S., 2002. Sea ice biological communities andnutrient dynamics in the Canada Basin of the Arctic Ocean. Deep-Sea Research I, 49, 1623-1649.

Mitchell, J.G., Silver, M.W., 1982. Modern archaeomonads indicate sea-ice environments. Nature, 296, 437-439.

Mitchell, J.G., Silver, M.W., 1986. Archaeomonad (chrysophyta) cysts: ecological and paleoecological significance. Biosystems, 19, 289-298.

Morán, X.A.G., López-Urrutia, Á., Calvo-Díaz, A., Li, W.K.W., 2010. Increasing importance of small phytoplankton in a warmer ocean. Global Change Biology, 16, 1137-1144.

Nadaï, G., Nöthig, E-M., Fortier, L., Lalande, C., 2021. Early snowmelt and sea ice breakup enhance algal export in the Beaufort Sea. Progress in Oceanography, 190, 102479, doi: https://doi.org/10.1016/j.pocean.2020.102479

Onodera, J., Takahashi, K., 2005. Silicoflagellate fluxes and environmental variations in the northwestern North Pacific during December 1997-May 2000. Deep-Sea Research I, 52, 371388.

Onodera, J., Takahashi, K., 2007. Diatoms and siliceous flagellates (silicoflagellates, ebridians, and endoskeletal dinoflagellate Actiniscus) from the Subarctic Pacific. Memoir of the Faculty of Science, Kyushu University, Series D. Earth Planet. Sci. XXXI, 105-136.

Onodera, J., Takahashi, K., 2012. Oceanographic conditions influencing silicoflagellate flux 
assemblages in the Bering Sea and subarctic Pacific Ocean during 1990-1994. Deep-Sea Research II, 61-64, 4-16.

Onodera, J., Takahashi, K., Honda, M.C., 2005. Pelagic and coastal diatom fluxes and the environmental changes in the northwestern North Pacific during December 1997-May 2000. Deep-Sea Research II, 52, 2218-2239.

Onodera, J., Watanabe, E., Harada, N., Honda, M.C., 2015. Diatom flux reflects watermass conditions on the southern Northwind Abyssal Plain, Arctic Ocean. Biogeosciences 12, 13731385 .

Onodera, J., Watanabe, E., Nishino, S., Harada, N., 2016. Distribution and vertical fluxes of silicoflagellates, ebridians, and the endoskeletal dinoflagellate Actiniscus in the western Arctic Ocean. Polar Biology, 39, 327-341.

Orr, W.N., Conley, S., 1976. Siliceous dinoflagellates in the northeast Pacific rim. Micropaleontology, 22, 92-99.

Peters, M.C., Andersen, R.A., 1993. The fine structure and scale formation of Chrysolepidomonas dendrolepidota gen. et sp. nov. (Chrysolepidomonadaceae fam. nov., Chrsyophyceae). Journal of Phycology, 29, 469-475.

Poelchau, H.S., 1976. Distribution of Holocene silicoflagellates in North Pacific sediments. Micropaleontology, 22, 164-193.

Proshutinsky, A., Johnson, M., 1997. Two circulation regimes of the wind-driven Arctic Ocean. Journal of Geophysical Research, 102, 12493-12514.

Proshutinsky, A., Dukhovskoy, D., Timmermans, M.-L., Krishfield, R., Bamber, J.L., 2015. Arctic circulation regimes. Philosophical Transactions of Royal Society A, 373, 20140160.

Ren, J., Chen, J., Bai, Y., Sicre, M.-A., Yao, Z., Lin, L., Zhang, J., Li, H., Wu, B., Jin, H., Ji, Z., Zhuang, Y., Li, Y., 2020. Diatom composition and fluxes over the Northwind Ridge, western Arctic Ocean: impact of marine surface circulation and sea ice distribution. Progress in Oceanography, 102377. https://doi.org/10.1016/j.pocean.2020.102377.

Redmond Roche, B.H., 2019. Diatoms as a sea-ice proxy - improving the accuracy of sea-ice reconstruction by re-analysing the northern North Atlantic training set for Fragilariopsis oceanica, Fragilariopsis reginae-jahniae and Fossula arctica, in addition to the chrysophyte cyst Archaeomonas sp. Master's Thesis. University of Helsinki.

Riaux-Gobin, C., Stumm, K., 2006. Modern Archaeomonadaceae from the land-fast ice off Adélie Land (Antarctica): a preliminary report. Antarctic Science, 18, 51-60. 
Riaux-Gobin, C., Poulin, M., Dieckmann, G., Labrune, C., Vétion, G., 2011. Spring phytoplankton onset after the ice break-up and sea-ice signature (Adélie Land, East Antarctica). Polar Research, 30, 5910, doi: 10.3402/polar.v30i0.5910

Saha, S., Moorthi, S., Pan, H.-L., Wu, X., Wang, J., Nadiga, S., Tripp, P., Kistler, R., Woollen, J., Behringer, D., Liu, H., Stokes, D., Grumbine, R., Gayno, G., Wang, J., Hou, Y.-T., Chuang, H., Juang, H.-M.H., Sela, J., Iredell, M., Treadon, R., Kleist, D., Delst, P.V., Keyser, D., Derber, J., Ek, M., Meng, J., Wei, H., Yang, R., Lord, S., van den Dool, H., Kumar, A., Wang, W., Long, C., Chelliah, M., Xue, Y., Huang, B., Schemm, J.-K., Ebisuzaki, W., Lin, R., Xie, P., Chen, M., Zhou, S., Higgins, W., Zou, C.- J., Z., Liu, Q., Chen, Y., Han, Y., Cucurull, L., Reynolds, R.W., Rutledge, G., Goldberg, M., 2010. The NCEP climate forecast system reanalysis. Bulletin of the American Meteorological Society, 91, 1015-1057.

Saha, S., Moorthi, S., Wu, X., Wang, J., Nadiga, S., Tripp, P., Behringer, D., Hou, Y.-T., Chuang, H.-Y., Iredell, M., Ek, M., Meng, J., Yang, R., Mendez, M.P., van den Dool, H., Zhang, Q., Wang, W., Chen, M., Becker, E., 2014. The NCEP climate forecast system version 2. Journal of Climate, 27, 2185-2208.

Sandgren, C.D., 1991. Chrysophyte reproduction and resting cysts: a paleolimnologist's primer. Journal of Paleolimnology, 5, 1-9.

Serreze, M.C., Barrett, A.P., Stroeve, J.C., Kindig, D.M., Holland, M., 2009. The emergence of surface-based Arctic amplification. The Cryosphere, 3, 9-11.

Silver, M.W., Mitchell, J.G., Ringo, D.L., I980. Siliceous nanoprankton II. Newly discovered cysts and abundant choanoflagellates from the Weddell Sea, Antarctica. Marine Biology, 58, 211-217.

Smol, J.P., 1988. Chrysophycean microfossils in paleolimnological studies. Palaeogeography, Palaeoclimatology, Palaeoecology, 62, 287-297.

Steidinger, K.A., Tangen, K., 1997. Dinoflagellates. In: Tomas, C. (Ed). Identifying Marine Phytoplankton. Academic Press. New York, USA. 387-584 pp.

Stickley, C.E., Koç, N., Brumsack, H.-J., Jordan, R.W., Suto, I., 2008. A siliceous microfossil view of middle Eocene Arctic paleoenvironments: A window of biosilica production and preservation. Paleoceanography, 23, PA1S14, doi:10.1029/2007PA001485

Takahashi, K., 1985. Two year time-series fluxes of silicoflagellates and Actiniscus: size fractioned results from subarctic Pacific Station PAPA, 1982-1984. Woods Hole Oceanographic Institution Technical Report, WHOI-85-41.

Takahashi, K., 1987. Seasonal fluxes of silicoflagellates and Actiniscus in the subarctic Pacific during 1982-1984. Journal of Marine Research, 45, 397-425. 
662

663

664

665

666

667

668

669

670

671

672

673

674

675

676

677

678

679

680

681

682

683

684

685

686

687

688

689

690

691

692

693

694

695

696

697

698

699

700

701

702

703

704

705

Takahashi, K., 1989. Silicoflagellates as productivity indicators: evidence form long temporal and spatial flux variability responding to hydrography in the north- eastern Pacific. Global Biogeochemical Cycles, 3, 43-61.

Takahashi, K., 1991. Silicoflagellates and Actiniscus: vertical fluxes at Pacific and Atlantic sediment trap stations. In: Ocean Biocoenosis, Honjo, S. (Ed.), Micropaleontology Press, NY.

Takahashi, E., Watanabe, K., Satoh, H., 1986. Siliceous cysts from Kita-No-Seto Strait, north of Syowa station, Antarctica. Memoirs of National Institute of Polar Research, Special Issue, 40, 84-95.

Takahashi, K., Onodera, J., Katsuki, K., 2009. Significant populations of seven-sided Distephanus (Silicoflagellata) in the sea-ice covered environment of the central Arctic Ocean, summer 2004. Micropaleontology, 55, 313-325.

Teraishi, A., Suto, I., Onodera, J., Takahashi, K., 2016. Diatom, silicoflagellate and ebridian biostratigraphy and paleoceanography in IODP 323 Hole U1343 at the Bering slope site. DeepSea Research II, 125-126, 18-28.

Tsutsui, H., Takahashi, K., 2009. Biometry of Distephanus medianoctisol (Silicoflagellata) in the sea-ice covered environment of the central Arctic Ocean, summer 2004. Memoirs of the faculty of sciences, Kyushu University, Series D, Earth and Planet Science, 32 (2), 57-68.

Walsh, J.J., Dieterle, D.A., Mullerkarger, F.E., Aagaard, K., Roach, A.T., Whitledge, T.E., Stockwell, D., 1997. $\mathrm{CO}_{2}$ cycling in the coastal ocean. II. Seasonal organic loading of the Arctic Ocean from source waters in the Bering Sea. Continental Shelf Research, 17, 1-36.

Wassmann, P., Duarte, C.M., Agusti, S., Sejr, M.K., 2011. Footprints of climate change in the Arctic marine ecosystem. Global Change Biology, 17, 1235-1249.

Wassmann, P., 2015. Overarching perspectives of contemporary and future ecosystems in the arctic ocean. Progress in Oceanography, 139, 1-12.

Weingartner, T.J., Danielson, S., Sasaki, Y., Pavlov, V., Kulakov, M., 1999. The Siberian Coastal Current: a wind and buoyancy-forced Arctic coastal current. Journal of Geophysical Research, 104, 29697-29713.

Wilkinson, A.N., Zeeb, B.A., Smol, J.P. 2001. Atlas of chrysophycean cysts. Kluwer Academic Publishers, Dordrecht, 169 pp.

Woodgate, R.A., 2018. Increases in the Pacific inflow to the Arctic from 1990 to 2015, and insights into seasonal trends and driving mechanisms from year-round Bering Strait mooring data. Progress in Oceanography, 160, 124-154. 
Woodgate, R.A., Aagaard, K., Weingartner, T.J., 2005. Monthly temperature, salinity, and transport variability of the Bering Strait throughflow. Geophysical Research Letter, 32 (4) L04601. https://doi.org/10.1029/2004GL021880.

Woodgate, R.A., Weingartner, T.J., Lindsay, R., 2012. Observed increases in Bering Strait oceanic fluxes from the Pacific to the Arctic from 2001 to 2011 and their impacts on the Arctic Ocean water column. Geophysical Research Letter, 39, L24603.

Woodgate, R., 2013. Arctic Ocean Circulation: Going Around At the Top Of the World. Nature Education Knowledge, 4(8):8

Woodgate, R.A., Stafford, K.M., Prahl, F.G., 2015. A Synthesis of Year-Round Interdisciplinary Mooring Measurements in the Bering Strait (1990-2014) and the RUSALCA Years (20042011). Oceanography, 28, 46-67.

Woodgate, R.A., 2018. Increases in the Pacific inflow to the Arctic from 1990 to 2015, and insights into seasonal trends and driving mechanisms from year-round Bering Strait mooring data. Progress in Oceanography, 160, 124-154. https://doi.org/10.1016/j.pocean. 2017.12.007.

Zeeb, B.A., Smol, J.P., 2001. Chryosophyte scales and cysts. In: Smol, J.P., Birks, H.J.B., Last, W.M. (Eds), Tracking Environmental Change Using Lake Sediments, vol. 3, Terrestrial, Algal, and Siliceous Indicators, Kluwer Acad., Norwell, Mass. 203 - 223 pp.

Zernova, V.V., Nöthig, E.-M., Shevchenko, V.P., 2000. Vertical microalga flux in the Northern Laptev Sea (from the data collected by the yearlong sediment trap). Oceanology, 40, 801-808.

Zhang, H., 2009. The Scientific Report on the $3^{\text {rd }}$ Chinese National Arctic Research Expedition. Ocean Express, Beijing, 225pp (in Chinese). 
1 Siliceous micro- and nanoplankton fluxes over the Northwind Ridge

2 and their relationship to environmental conditions in the western 3 Arctic Ocean

4

$5 \quad$ Jian Ren et al

6

7

8 Table 1 
Table 1.

Table 1. Matrix of coefficient of determination $\left(r^{2}\right)$ between fluxes of chrysophyte cysts, silicoflagellate and endoskeletal dinoflagellate Actiniscus pentasterias, fluxes of sea ice diatom and cold water diatom group, fluxes of brassicasterol and dinosterol and fluxes of IP $_{25}$ and HBI-III from August 2008 to September 2009 at Station DM. Significant correlations are bold and underlined.

\begin{tabular}{|c|c|c|c|c|c|c|c|c|c|}
\hline & $\begin{array}{l}\text { Chrysophyte cyst } \\
\text { flux }\end{array}$ & $\begin{array}{l}\text { Silicoflagellate } \\
\text { flux }\end{array}$ & $\begin{array}{l}\text { Actiniscus } \\
\text { pentasterias flux }\end{array}$ & $\begin{array}{l}\text { Sea ice } \\
\text { diatom flux }\end{array}$ & $\begin{array}{l}\text { Cold water } \\
\text { diatom flux }\end{array}$ & $\begin{array}{l}\text { Brassicasterol } \\
\text { flux }\end{array}$ & $\begin{array}{l}\text { Dinosterol } \\
\text { flux }\end{array}$ & $\begin{array}{l}\mathbf{I P}_{25} \\
\text { flux }\end{array}$ & $\begin{array}{l}\text { HBI-III } \\
\text { flux }\end{array}$ \\
\hline Chrysophyte cyst flux ${ }^{a}$ & 1.00 & & & & & & & & \\
\hline Silicoflagellate flux $\mathrm{x}^{\mathrm{a}}$ & 0.04 & 1.00 & & & & & & & \\
\hline Actiniscus pentasterias flux $\mathrm{x}^{\mathrm{a}}$ & 0.02 & $\underline{0.97}^{*}$ & 1.00 & & & & & & \\
\hline Sea ice diatom flux ${ }^{b}$ & $0.31^{*}$ & $0.33^{*}$ & $0.24^{* *}$ & 1.00 & & & & & \\
\hline Cold water diatom flux ${ }^{b}$ & $0.40^{*}$ & $\underline{0.71}^{*}$ & $\underline{0.65}^{*}$ & $\underline{0.64}^{*}$ & 1.00 & & & & \\
\hline Brassicasterol flux ${ }^{\mathrm{c}}$ & 0.14 & $\underline{0.91}^{*}$ & $\underline{0.88}^{*}$ & $0.44^{*}$ & $\underline{0.83}^{*}$ & 1.00 & & & \\
\hline Dinosterol flux ${ }^{c}$ & $\underline{0.56}^{*}$ & $0.43^{*}$ & $0.40^{*}$ & $\underline{0.56}^{*}$ & $\underline{0.77^{*}}$ & $\underline{0.67^{*}}$ & 1.00 & & \\
\hline IP $_{25}$ flux $^{d}$ & 0.14 & 0.01 & $<0.001$ & $\underline{0.64}^{*}$ & 0.16 & 0.03 & 0.08 & 1.00 & \\
\hline HBI-III flux ${ }^{d}$ & $<0.003$ & 0.01 & $<0.001$ & $0.48^{*}$ & 0.03 & 0.01 & 0.02 & $\underline{0.75}^{*}$ & 1.00 \\
\hline
\end{tabular}

${ }^{a}$ in $10^{3}$ cysts/skeletons $\mathrm{m}^{-2} \mathrm{~d}^{-1}$

${ }^{b}$ in $10^{5}$ valves $\mathrm{m}^{-2} \mathrm{~d}^{-1}$

$\mathrm{c}$ in $\mu \mathrm{g} \mathrm{m}^{-2} \mathrm{~d}^{-1}$

$\mathrm{d}$ in $\mathrm{ng} \mathrm{m}^{-2} \mathrm{~d}^{-1}$

${ }^{*} p$-value $<0.01$

${ }^{* *} p$-value $<0.05$ 
1 Siliceous micro- and nanoplankton fluxes over the Northwind Ridge

2 and their relationship to environmental conditions in the western 3 Arctic Ocean

4

5 Jian Ren et al

6

7

$8 \quad$ Figure captions 
Figure 1. (a) Station DM (red circle) and surface currents (grey arrows) in the study area. The white dash line represents the average multi-year sea ice minimum for 1979-2017 (20\% of sea ice concentration) (from Cavalieri et al., 1996). The other site for discussion is also presented (yellow circle). Major currents system: PWI- Pacific Water Inflow; ACW-Alaska Coastal Water; AW-Anadyr Water; BSW-Bering Shelf Water; BG-Beaufort Gyre; SCC-Siberia Coastal Current. Topography: NR-Northwind Ridge; NAP-Northwind Abyssal Plain; CP-Chukchi Plateau; CAP-Chukchi Abyssal Plain. The inset figure in the upper right indicates the study area in the Arctic Ocean. (b) and (c) demonstrate the surface currents and sea ice distribution near Station DM in summer 2008 and 2009, respectively (modified from Ren et al., 2020). The black dash line indicates the $20 \%$ isoline of summer sea ice concentration (July, August and September). Stronger currents are shown by thicker arrows. Sea ice data were obtained from Nimbus-7 SMMR and DMSP SSM/I-SSMIS passive microwave data (Cavalieri et al., 1996).

Figure 2. Sea ice and sea surface environment variability and siliceous micro- and nanoplankton fluxes measured in the sediment trap at Station DM from August 2008 to September 2009. (a) Sea ice concentration (\%); (b) Sea ice thickness (m); (c) Arctic Ocean Oscillation Index, indicating the strength of the Beaufort Gyre (from Proshutinsky et al., 2015); (d) Transport of the Pacific Water Inflow (Sv; Woodgate et al., 2015; Woodgate 2018). Maximum transport of 2008 and 2009 is also indicated; (e) Total mass flux ( $\mathrm{mg} \mathrm{m}^{-2} \mathrm{~d}^{-1}$; from Bai et al., 2019); (f) Total silicoflagellate fluxes $\left(10^{3}\right.$ skeletons $\left.\mathrm{m}^{-2} \mathrm{~d}^{-1}\right)$; (g) Actiniscus pentastarias fluxes $\left(10^{3}\right.$ skeletons $\left.\mathrm{m}^{-2} \mathrm{~d}^{-1}\right)$; (h) Chrysophyte cyst fluxes $\left(10^{3}\right.$ cysts $\left.\mathrm{m}^{-2} \mathrm{~d}^{-1}\right)$.

Figure 3. (a) Stacked fluxes of main silicoflagellate species $\left(10^{3}\right.$ skeletons $\left.\mathrm{m}^{-2} \mathrm{~d}^{-1}\right)$; (b) Relative abundance of main silicoflagellate species (\%).

Figure 4. Scanning Electron Microscope (SEM) photomicrographs of silicoflagellates (a-c), endoskeletal dinoflagellate Actiniscus pentasterias (d-f) and chrysophyte cysts (g-i) obtained from the samples of Station DM. (a) Stephanocha speculum; (b) S. medianoctisol (internal view); (c) S. octonarius; (d) Apical view of A. pentasterias; (e) Oblique basal view of $A$. pentasterias; (f) Side view of A. pentasterias; (g) chrysophyte cyst type 1 (stomatocyst 382 in Wilkinson et al., 2001); (h) chrysophyte cyst type 2 (stomatocyst 381 in Wilkinson et al., 2001); (i) cluster of chrysophyte cyst type 1 . Scale bars are $10 \mu \mathrm{m}$ for a-c and $5 \mu \mathrm{m}$ for $\mathrm{d}-\mathrm{i}$.

Figure 5. Fluxes of chrysophyte cysts $\left(10^{3}\right.$ cysts $\left.\mathrm{m}^{-2} \mathrm{~d}^{-1}\right)$ and sea ice diatom $\left(10^{5}\right.$ valves $\left.\mathrm{m}^{-2} \mathrm{~d}^{-1}\right)$. Sea ice concentration is also shown. 
48 Siliceous micro- and nanoplankton fluxes over the Northwind Ridge and

49 their relationship to environmental conditions in the western Arctic Ocean

50

51 Jian Ren et al

52

53

$54 \quad$ Figures 1-5

55 

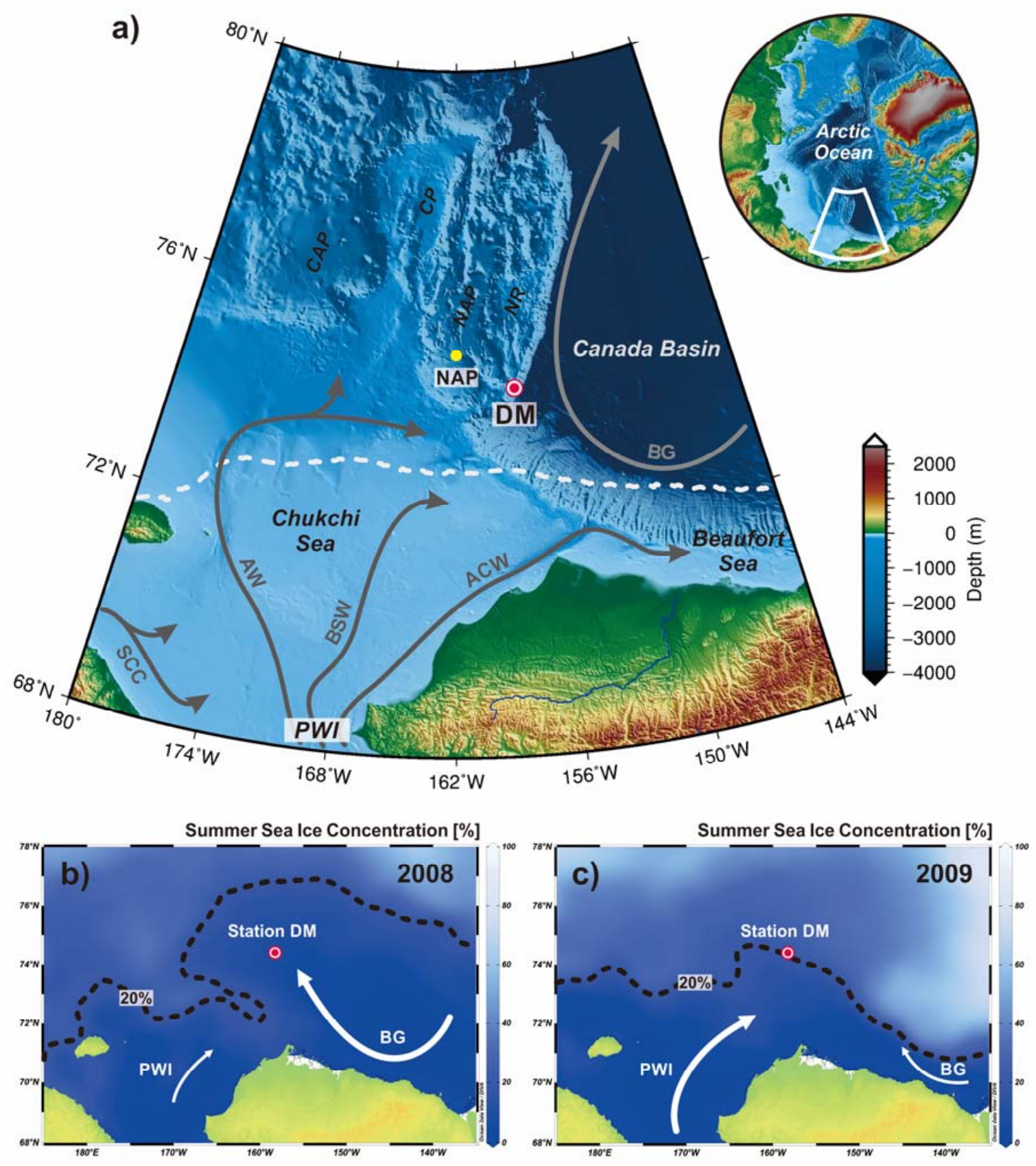


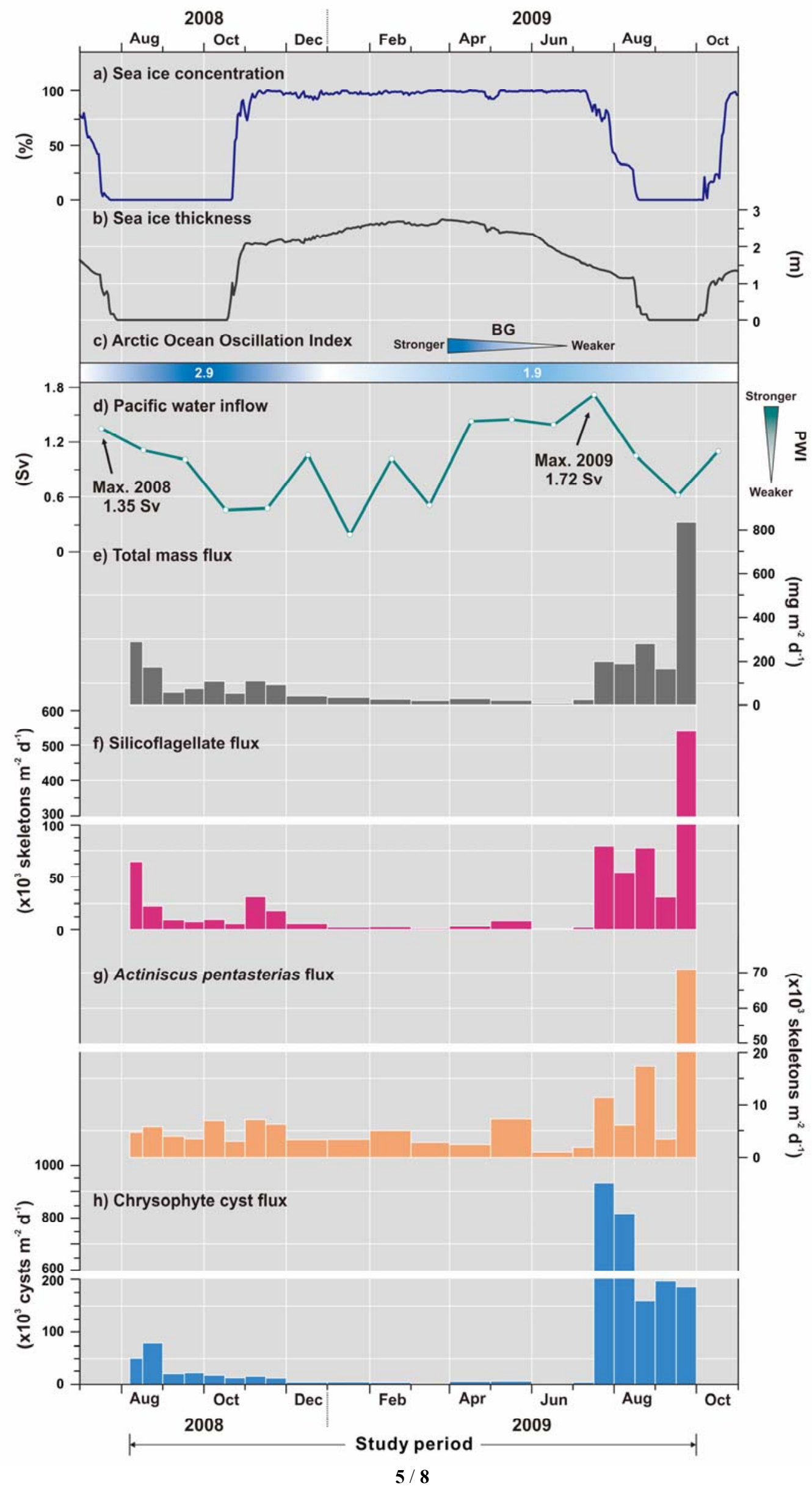



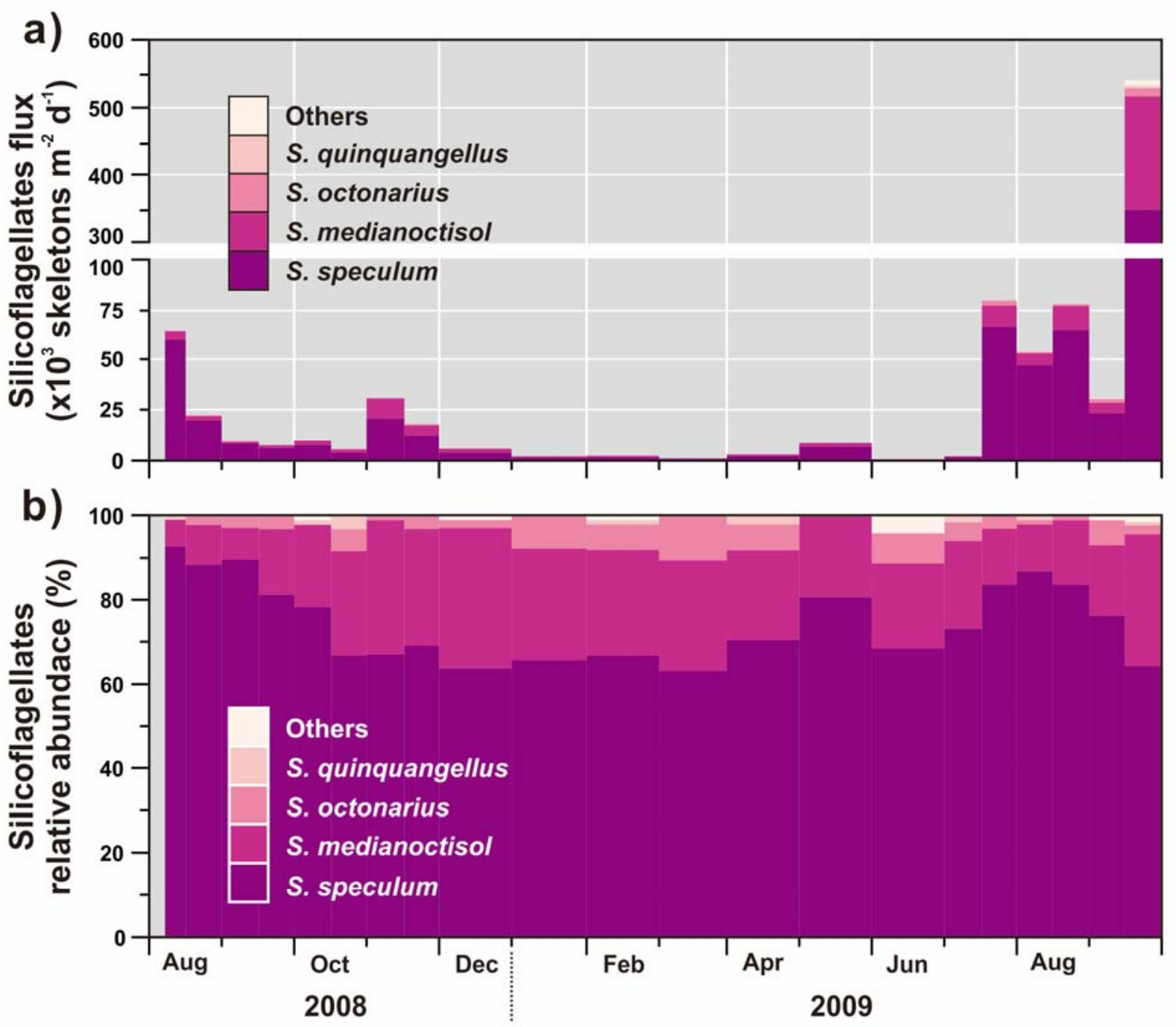
Figure 4
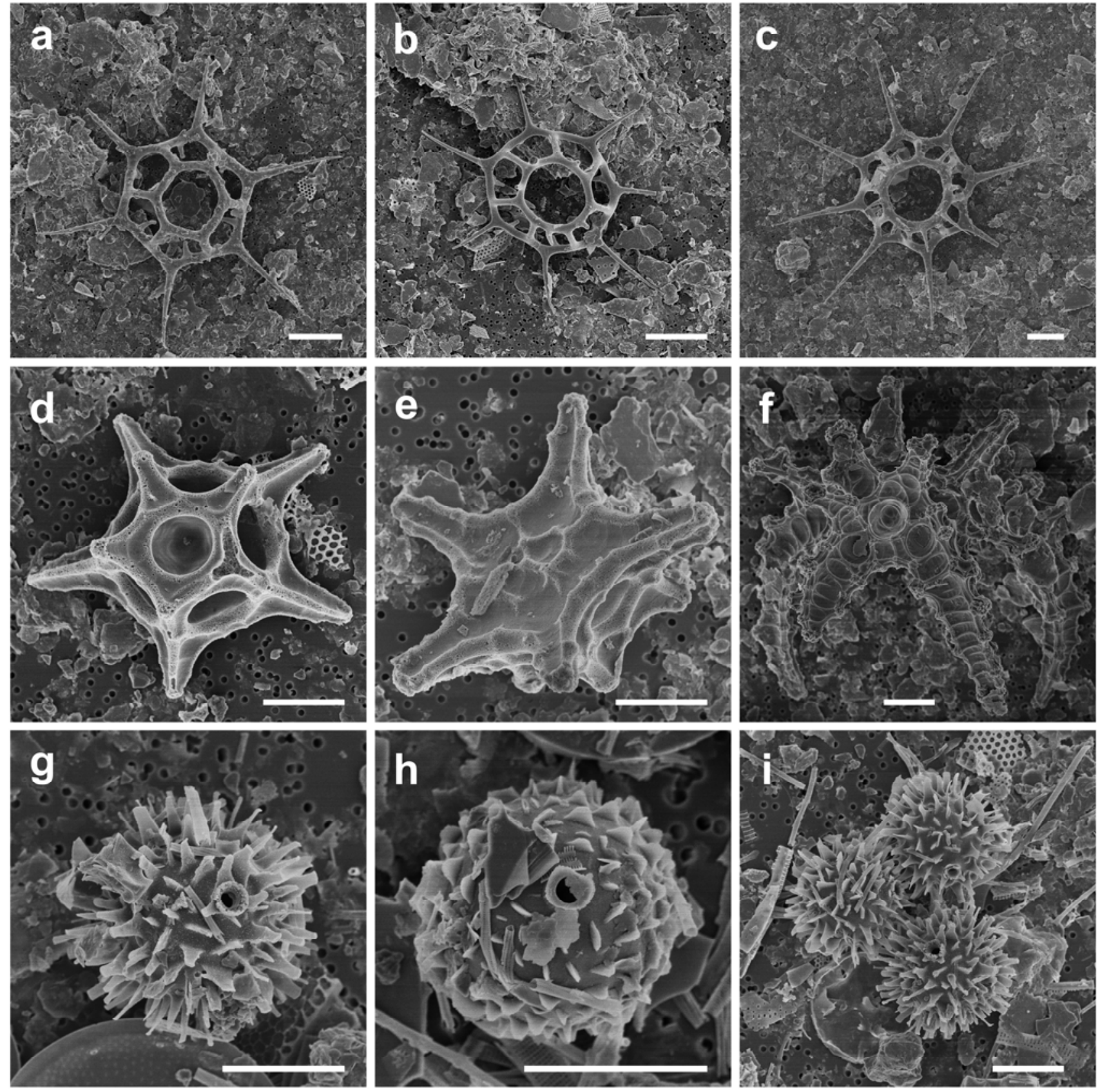

63

64 


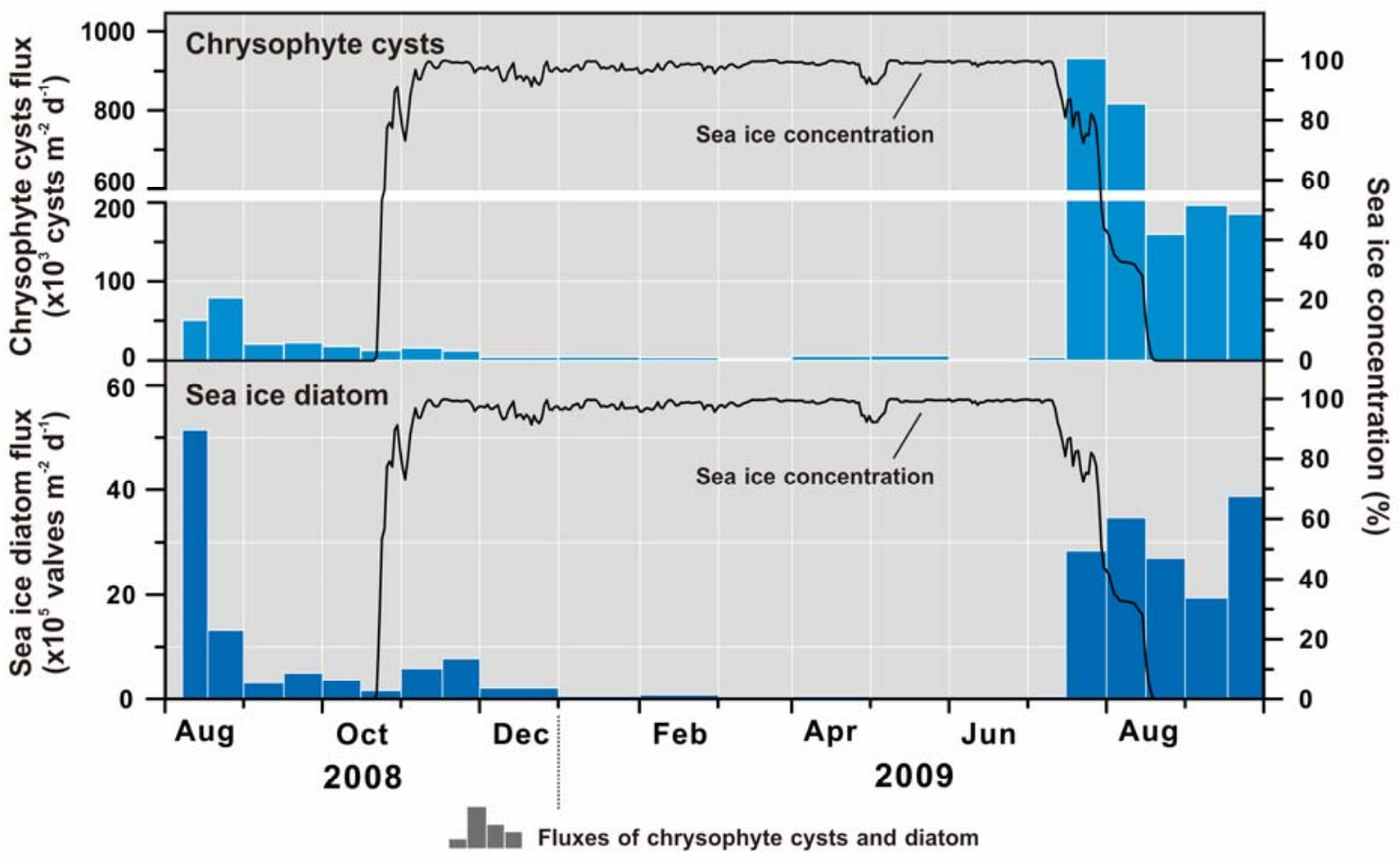

67 